
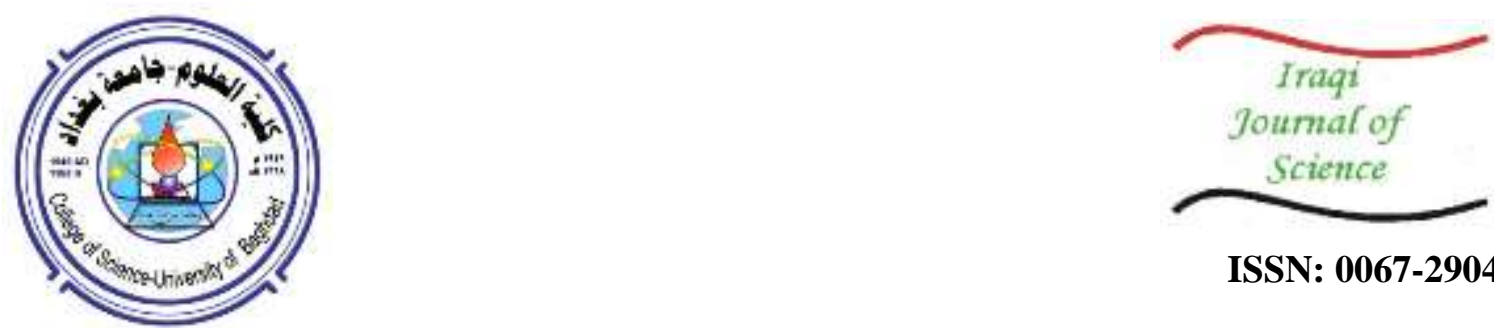

ISSN: 0067-2904

\title{
Enhancement of the Efficiency of the CZTS/Cds/Zno/ITO Solar Cell By Back Reflection and Buffer Layers Using SCAPS -1D
}

\author{
Hardan T. Ganem*, Ayed N. Saleh \\ Department of Physics, Collage of Education for Pure Science, Tikrit University, Tikrit, Iraq
}

Received: $14 / 5 / 2020$

Accepted: 6/7/2020

\begin{abstract}
CZTS / CdS / ZnO / ITO solar cell was studied using Solar Cell Capacitance Simulato-1D (SCAPS-1D) program. We performed an improvement on the theoretical cell by increasing the doping and thickness of some layers. As a result, the efficiency was shifted from $2.18 \%$ to $6.17 \%$ and several back reflection layers (BSL) were introduced on the enhanced cell until. We obtained a highest conversion efficiency of $13.99 \%$. The best reflection layer (CZTSSe) was combined with the best buffer layer $(\mathrm{CdSe})$, with thickness of $0.9 \mu \mathrm{m}$, on the enhanced cell. Thereby, we obtained a cell with a conversion efficiency of $16.53 \%$. A second improvement was made to the best obtained cell, where the CZTSSe with thickness of $0.05 \mu \mathrm{m}$ and the CdSe with thickness of $0.9 \mu \mathrm{m}$ were combined. Consequently, the efficiency was increased from $16.53 \%$ to $21.76 \%$. By comparing the experimental results with those obtained with the program, it was found that the program simulates reality, i.e. the experimental and theoretical results matched.
\end{abstract}

Keywords: SCAPS-D, Simulation solar cells CZTS, Add BSL and buffer layers.

\section{تعزيز كفاءة الظلية الثمسية CZTS/CdS/ZnO/ITO بوساطة الطبقات BSL و Buffer باستخدام SCAPS-1D}

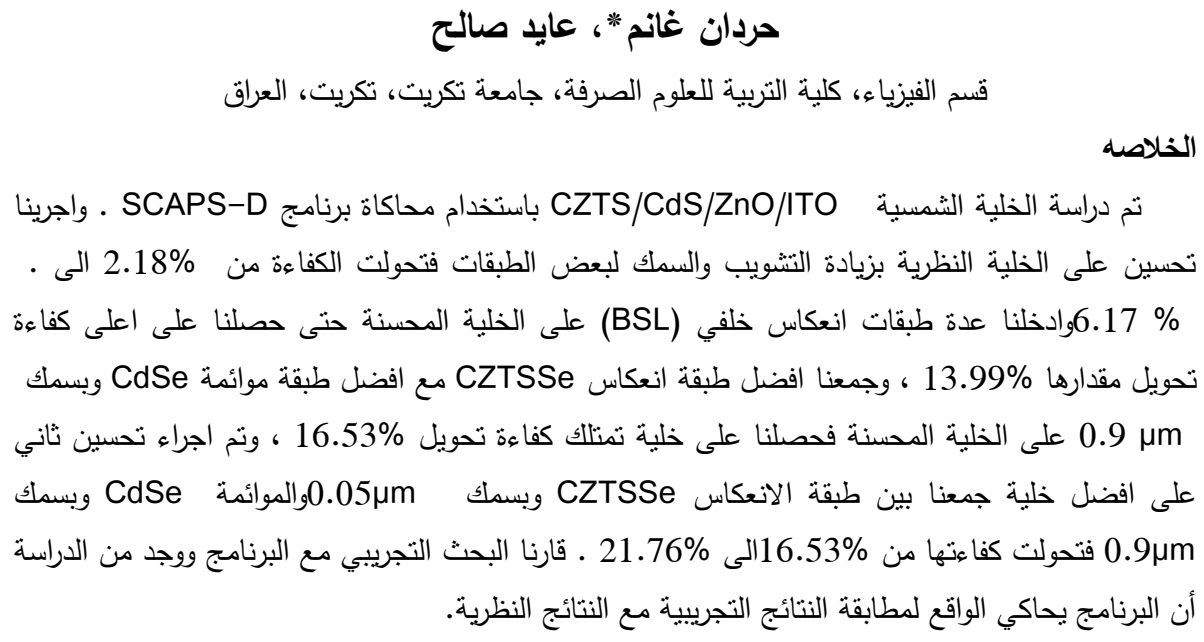

\section{Introduction}

Semiconductors absorb photons that have more energy than the prohibited energy gap and lose excess energy by thermal, radiate, or non-radiate processes. There are efforts to increase their 
efficiency by manufacturing various solar cells [1]. For decades, researchers have been interested in using copper indium gallium selenide (CIGS) and cadmium telluride ( CdTe ) in the manufacturing of thin film solar cells, because these materials are highly efficient. Nevertheless, they require high costs and occupy a large area, some are rare and others are toxic. For these reasons, researchers have sought to replace these materials with others. They found that non-toxic alternative materials such as copper zinc tin sulfide (CZTS) are available and have good electrical and optical properties, as their efficiency is $8.4 \%$. However, this efficiency level is low as compared to that of CIGS, which is $20 \%$. This is due to the different mechanisms of loss resulting from the nature of absorption. Therefore, the effects of thickness, doping, and defects must be analyzed to increase the efficiency of the cell [2]. New compounds can be studied by replacing $\mathrm{Zn}$ with certain elements (e.g. $\mathrm{Ni}, \mathrm{Fe}, \mathrm{Cd}, \mathrm{Be}, \mathrm{Mg}, \mathrm{Mn}$ ) and other elements called quaternary chalcogenides. These elements are available in the Earth's crust, have low cost on production, non-toxic, have an energy gap near to the ideal value, and have a high absorption coefficient $[3,4]$. Thus, thin films are made of these materials.

$\mathrm{Cu}_{2} \mathrm{ZnSnS}_{4}$ (CZTS) thin film solar cells can be made using many kinds of technologies, such as spin coating, electrostatic deposition, etc. In 1988, Ito and Nakazawa discovered for the first time the photovoltaic effect of a CZTS film with an efficiency of $0.66 \%$. Wang et al. scored the highest conversion efficiency of $12.6 \%$, while the reported efficiencies were still far below the physical limit of 32\% [5]. Therefore, numerical simulation has become an economical and effective method for predicting changes in cell properties.

CZTS is a semiconductor compound that is available, inexpensive, and has a direct power gap of $1.5 \mathrm{eV}$, refractive index of 2.07, a high absorption coefficient of $10^{4} \mathrm{~cm}^{-1}$, and suitable conversion efficiency [6]. In this paper, we changed the stimulants and thickness of the layers, entered BSL reflection layers and an insulating layer, and then collected the best reflective and buffer layers. Ultimately, we compared the experimental cells with the theoretical cells to obtain a highly efficient cell.

\section{Modeling}

\subsection{Numerical simulation in SCAPS-1D}

Modeling can be performed using the SCAPS software. It is a one dimensional solar cell simulation program designed at the University of Gent in Belgium to simulate the classical crystals of semiconductor materials (CIGS or CdTe) or other materials, such as SnS. Also, the user can describe a cell with a maximum of seven layers for different properties, such as optical absorption, thickness, and doping concentration, among others [7]. SCAPS is designed to simulate J-V characteristic curve.analysis, ac (C-V and C-f) properties, and device spectral response quantum efficiency ( $\mathrm{QE}$ ). This program has been developed and applied to all solar cells. It is a freely available program that depends on the solution of semiconductor equations. We start by writing the Poisson equation: [8]

$$
\nabla(E)=\frac{q}{\varepsilon}\left(p-n+N_{D}^{+}-N_{A}^{-}\right) \quad----1
$$

where $\mathrm{E}$ is electrical field, $q$ is elementary charge, $\varepsilon$ is permittivity of the absorber, $\mathrm{n}(\mathrm{p})$ is density of electrons (holes), and $\mathrm{N}_{\mathrm{D}}\left(\mathrm{N}_{\mathrm{A}}\right)$ is donor (acceptor) concentration .

Then, we apply the continuity equation that is given by the following relationship:[9]

$$
\begin{array}{lr}
\frac{d n}{d t}=\frac{1}{q}\left(\nabla\left(J_{n}\right)+G_{n}-R_{n}\right. & -------2 \\
\frac{d p}{d t}=-\frac{1}{q}\left(\nabla\left(J_{p}\right)+G_{p}-R_{p}\right. & ------3
\end{array}
$$

where $J_{n}\left(J_{p}\right)$ is electron ( hole) current density, $G_{n}\left(\mathrm{G}_{\mathrm{p}}\right)$ is electron (hole) generation rate, and $R_{n}$ $\left(\mathrm{R}_{p}\right)$ is electron (hole ) recombination rate.

Finally, the charge carrier equations for the density of diffusion current and drift can be obtained from the following equations:[10]

$$
\begin{array}{cc}
J_{n}=q\left(\mu_{n} n E+D_{n} \nabla n\right) & -------4 \\
J_{p}=q\left(\mu_{p} P E+D_{p} \nabla p\right) & --------5
\end{array}
$$

where $\mu_{\mathrm{n}}\left(\mu_{\mathrm{p}}\right)$ is electron (hole) mobility and $\mathrm{D}$ is the diffusion constant.

There are many basic equations that explain the work of solar cells. The following equation gives the total current (the sum of the luminescence current $\mathrm{I}_{\mathrm{L}}$ and the dark current): $[8,10]$ 


$$
I=I_{o}\left[\exp \left(\frac{q v}{K T}\right)-1\right]-I_{L} \quad-------6
$$

where $\mathrm{K}$ is Boltzmann's constant and $\mathrm{T}$ is temperature in Kelvin.

To find the properties of the (V-I) curve of the solar cell under lighting, an open circuit voltage $\left(\mathrm{V}_{\mathrm{oc}}\right)$ is the maximum voltage when the current is zero. The $\mathrm{V}_{\mathrm{oc}}$ equation can be obtained by making the total current of equation (6) equal to zero, so the equation becomes:

$$
\mathrm{V}_{\mathrm{oc}}=\frac{\mathrm{KT}}{\mathrm{q}} \operatorname{Ln}\left(\frac{\mathrm{I}_{\mathrm{L}}}{\mathrm{I}_{\mathrm{o}}}-1\right) \approx \frac{\mathrm{KT}}{\mathrm{q}} \operatorname{Ln}\left(\frac{\mathrm{I}_{\mathrm{L}}}{\mathrm{I}_{\mathrm{o}}}\right) \quad----7
$$

where $I_{0}$ represents the saturation current of the diode and can be calculated through the following equation:

$$
\mathrm{I}_{\mathrm{o}}=\mathrm{DT}^{3} \exp \left[\frac{-\mathrm{E}_{\mathrm{g}}}{\mathrm{KT}}\right]=\mathrm{A}\left[\frac{\mathrm{q} \mathrm{D}_{\mathrm{e}} \mathrm{n}_{\mathrm{i}}^{2}}{\mathrm{~L}_{\mathrm{e}} \mathrm{N}_{\mathrm{A}}}+\frac{\mathrm{qD}_{\mathrm{h}} \mathrm{n}_{\mathrm{i}}^{2}}{\mathrm{~L}_{\mathrm{h}} \mathrm{N}_{\mathrm{D}}}\right] \quad-----8
$$

where Eg is energy gap, $\mathrm{L}_{\mathrm{e}}\left(\mathrm{L}_{\mathrm{h}}\right)$ is diffusion length electrons (holes), and A is diode cross-section .

From equation (7), we observe the logarithmic increase of the open circuit voltage as the saturation current decreases. The short circuit current $\mathrm{I}_{\mathrm{sc}}$ is obtained when the open circuit voltage is zero. In the ideal case, the short circuit current is equal to the optical current. The relationship between the short circuit current and the open circuit voltage can be written as follows:

$$
\mathrm{I}_{\mathrm{sc}}=\mathrm{I}_{\mathrm{o}}\left[\mathrm{e}^{\mathrm{qv_{oc }} / \mathrm{KT}}-1\right]
$$

To measure the quality of the photovoltaic cells, the fill factor (FF), short circuit current, voltage circuit open, and conversion efficiency $(\eta)$ should be found, as these variables are related to each other. They can be calculated by the following equations:[10]

$$
\begin{aligned}
& \mathrm{FF}=\frac{\mathrm{P}_{\max }}{\mathrm{P}_{\text {in }}}=\frac{\mathrm{V}_{\max } \mathrm{I}_{\max }}{V_{\text {oc }} \mathrm{J}_{\mathrm{Sc}}} \\
& \eta=\frac{\stackrel{P}{\text { in }}_{\mathrm{m}}}{\mathrm{P}_{\text {in }}}=\frac{\mathrm{J}_{\mathrm{sc}} \cdot \mathrm{V}_{\mathrm{oc}} \cdot \mathrm{FF}}{\mathrm{P}_{\text {in }}} \quad------11
\end{aligned}
$$

where $V_{\max }$ is the highest voltage, $\mathrm{P}_{\max }$ is the highest power, $\mathrm{I}_{\max }$ is the highest current, and $\mathrm{P}_{\text {in }}$ is the incoming power.

The lift time of minority carriers should be determined, which is the average time to recombine minority carriers. It is associated with the concentration of doping and recombination, and can be found with the following relationship [7]:

$$
\begin{array}{cr}
\tau=\frac{1}{\sigma V_{t h} N_{t}} & ---------12 \\
\tau=\frac{\Delta \mathrm{n}}{\mathrm{R}} & ------------13
\end{array}
$$

where $\tau$ is minority carrier life time, $N_{t}$ is defects concentration, $V_{\text {th }}$ is thermal speed , $\sigma$ is conductivity, $\mathrm{R}$ is recombination rate, and $\Delta \mathrm{n}$ is excess minority carrier concentration.

\subsection{Solar cell structure}

The CZTS /CdS /ZnO /ITO solar cell is made of ZnO / ITO window layer of transparent metal oxides having a relatively large energy gap. Then, the buffer layer CdS has a suitable energy gap between the absorption layer and the window, i.e. the CZTS absorption layer, which has a relatively small energy gap. Front and back contacts are made from aluminum and gold with work function values of $5.25 \mathrm{eV}$ and $4.1 \mathrm{eV}$, respectively [11]. Figure-1 shows the structure of the solar cell.

\begin{tabular}{|c|}
\hline AL (front) \\
\hline Window Layer [ITO/ZnO] \\
\hline buffer Layer CdS \\
\hline absorption Layer CZTS \\
\hline (back) Au \\
\hline glass \\
\hline
\end{tabular}

Figure 1-Structure of the solar cell.

In this study, the series resistance, the parallel resistance, and the temperature are taken as $3 \Omega \mathrm{cm}^{2}$ , $400 \Omega \mathrm{cm}^{2}$, and $304 \mathrm{k}$, respectively. Table-1 gives the values of the parameters and defect values for 
the layer mentioned above, which must be entered on the SCAPS program to study the experimental cell performance. Improvement of the efficiency of solar cells can be achieved by means of addressing.the following facts:

- Comparing the experimental cell with the theoretical cell.

- Improving the theoretical cell.

- Comparing the theoretical cell before and after improvement.

- Adding various layers of back reflection to increase cell efficiency.

- Adding various buffer layers to improve cell performance.

- Combining the best buffer layer with different reflection layers to achieve the best cell.

- Improving the best cell combination between reflection and buffer layers

Table 1-The physical parameters of different layers with interface defects

\begin{tabular}{|c|c|c|c|c|c|c|}
\hline Parameters & $\begin{array}{l}\text { symbol } \\
\text { (unit) }\end{array}$ & CZTS & $\mathrm{CdS}$ & $\mathrm{ZnO}$ & ITO & $\begin{array}{c}\text { Defect of } \\
\text { interface } \\
\text { CZTS/CdS }\end{array}$ \\
\hline Thickness & $\mathrm{W}(\mu \mathrm{m})$ & $0.75[12]$ & $0.06[12]$ & $0.05[12]$ & $0.23[12]$ & \\
\hline Band gap & Eg (ev) & $1.47[12]$ & $2.4[14]$ & $3.3[9]$ & $3.6[16]$ & \\
\hline Electron affinity & $\chi(\mathrm{ev})$ & $4.5[13]$ & $4.5[14]$ & $4.6[9]$ & $4.1[16]$ & \\
\hline $\begin{array}{c}\text { Dielectric } \\
\text { permittivity }\end{array}$ & $\varepsilon_{\mathrm{r}}$ & $10[13]$ & $10[14]$ & 9 [9] & $10[16]$ & \\
\hline $\begin{array}{l}\text { CB effective density } \\
\text { of states }\end{array}$ & $\mathrm{N}_{\mathrm{C}}\left(\mathrm{cm}^{-3}\right)$ & $\begin{array}{c}2.2 \times \\
10^{18}[13]\end{array}$ & $\begin{array}{c}2.2 \times \\
10^{18}[14]\end{array}$ & $\begin{array}{c}2.2 \times \\
10^{18}[9]\end{array}$ & $\begin{array}{c}2.2 \times \\
10^{18}[17]\end{array}$ & \\
\hline $\begin{array}{l}\text { VB effective density } \\
\text { of states }\end{array}$ & $\mathrm{N}_{\mathrm{V}}\left(\mathrm{cm}^{-3}\right)$ & $\begin{array}{c}1.8 \times \\
10^{19}[13]\end{array}$ & $\begin{array}{c}1.8 \times \\
10^{19}[14]\end{array}$ & $\begin{array}{c}1.8 \times \\
10^{19}[9]\end{array}$ & $\begin{array}{c}1.8 \times \\
10^{19}[17] \\
\end{array}$ & \\
\hline $\begin{array}{c}\text { Electron thermal } \\
\text { velocity }\end{array}$ & $\mathrm{V}_{\mathrm{n}}(\mathrm{cm} / \mathrm{s})$ & $\begin{array}{c}1.0 \times \\
10^{7}[13] \\
\end{array}$ & $\begin{array}{c}1.0 \times \\
10^{7}[14] \\
\end{array}$ & $\begin{array}{c}1.0 \times \\
10^{7}[9] \\
\end{array}$ & $\begin{array}{c}1.0 \times \\
10^{7}[17] \\
\end{array}$ & \\
\hline $\begin{array}{l}\text { Hole thermal } \\
\text { velocity }\end{array}$ & $\mathrm{V}_{\mathrm{P}}(\mathrm{cm} / \mathrm{s})$ & $\begin{array}{c}1.0 \times \\
10^{7}[13] \\
\end{array}$ & $\begin{array}{c}1.0 \times \\
10^{7}[14]\end{array}$ & $\begin{array}{c}1.0 \times \\
10^{7}[9] \\
\end{array}$ & $\begin{array}{c}1.0 \times \\
10^{7}[17] \\
\end{array}$ & \\
\hline Electron mobility & $\mu_{\mathrm{n}}\left(\mathrm{cm}^{2} / \mathrm{v} . \mathrm{s}\right)$ & $100[13]$ & $100[15]$ & $100[9]$ & $100[17]$ & \\
\hline Hole mobility & $\mu_{\mathrm{p}}\left(\mathrm{cm}^{2} / \mathrm{v} \cdot \mathrm{s}\right)$ & $25[13]$ & $25[15]$ & $25[9]$ & $25[17]$ & \\
\hline $\begin{array}{c}\text { Shallow uniform } \\
\text { donor density }\end{array}$ & $\mathrm{N}_{\mathrm{D}}\left(1 / \mathrm{cm}^{3}\right)$ & 0 & $\begin{array}{l}1.0 \times \\
10^{21} \\
\end{array}$ & $\begin{array}{l}1.0 \times \\
10^{15} \\
\end{array}$ & $1.0 \times 10^{17}$ & \\
\hline $\begin{array}{l}\text { Shallow uniform } \\
\text { acceptor density }\end{array}$ & $\mathrm{N}_{\mathrm{A}}\left(1 / \mathrm{cm}^{3}\right)$ & $3.3 \times 10^{15}$ & 0 & 0 & 0 & \\
\hline $\begin{array}{l}\text { Coefficient } \\
\text { absorption }\end{array}$ & $\alpha(1 / \mathrm{cm})$ & $1.0 \times 10^{4}$ & scaps & scaps & $1.0 \times 10^{5}$ & \\
\hline $\begin{array}{c}\text { Capture cross } \\
\text { section area of } \\
\text { electrons and holes }\end{array}$ & $\left(\mathrm{cm}^{2}\right) \delta \mathrm{e}$ & & & & & $1 \times 10^{-19}$ \\
\hline $\begin{array}{l}\text { Energy level with } \\
\text { respect to reference }\end{array}$ & $\mathrm{E}_{\mathrm{t}}(\mathrm{eV})$ & & & & & 0.6 \\
\hline Total density & $\mathrm{N}_{\mathrm{t}}\left(\mathrm{cm}^{-2}\right)$ & & & & & $1.0 \times 10^{10}$ \\
\hline
\end{tabular}

\section{Results and Discussion}

\subsection{Comparing the experimental solar cell with the theory}

To simulate the performance of the solar cell, a comparison between the experimental design of Guo et al. [12] with the theoretical results was performed. The results of SCAPS program showed a high match between the experimental and theoretical results, as shown in Table-2. The defects of the CZTS / CdS interface contributed to this match. However, the incomplete match of the I-V curve, as shown in Figure -2, go to a decrease in the fill factor of the experimental cell that results in a decrease in the conversion efficiency. This is due to the presence of interface defects which decrease the minority carrier lifetime, according to equation (12), and thus increasing recombination, according to equation (13). 
Table 2-Theoretical and experimental results

\begin{tabular}{|l|l|l|l|l|l|c|c|c|}
\hline \multicolumn{2}{|c|}{ S } & cell structure & $\mathrm{V}(\mathrm{v})$ & $\mathrm{J}\left(\mathrm{mA} / \mathrm{cm}^{2}\right)$ & $\mathrm{FF} \%$ & $\eta \%$ \\
\hline 1. & & $\begin{array}{c}\text { ITO/ZnO/CdS/CZTS }( \\
\text { Experimental) }\end{array}$ & 0.37 & 13.14 & 37.9 & 1.93 \\
\hline 2 & $\begin{array}{c}\text { ITO/ZnO/CdS/CZTS } \\
\text { (Theoretical) }\end{array}$ & 0.38 & 13.32 & 41.92 & \multicolumn{7}{|c|}{2.18} \\
\hline
\end{tabular}

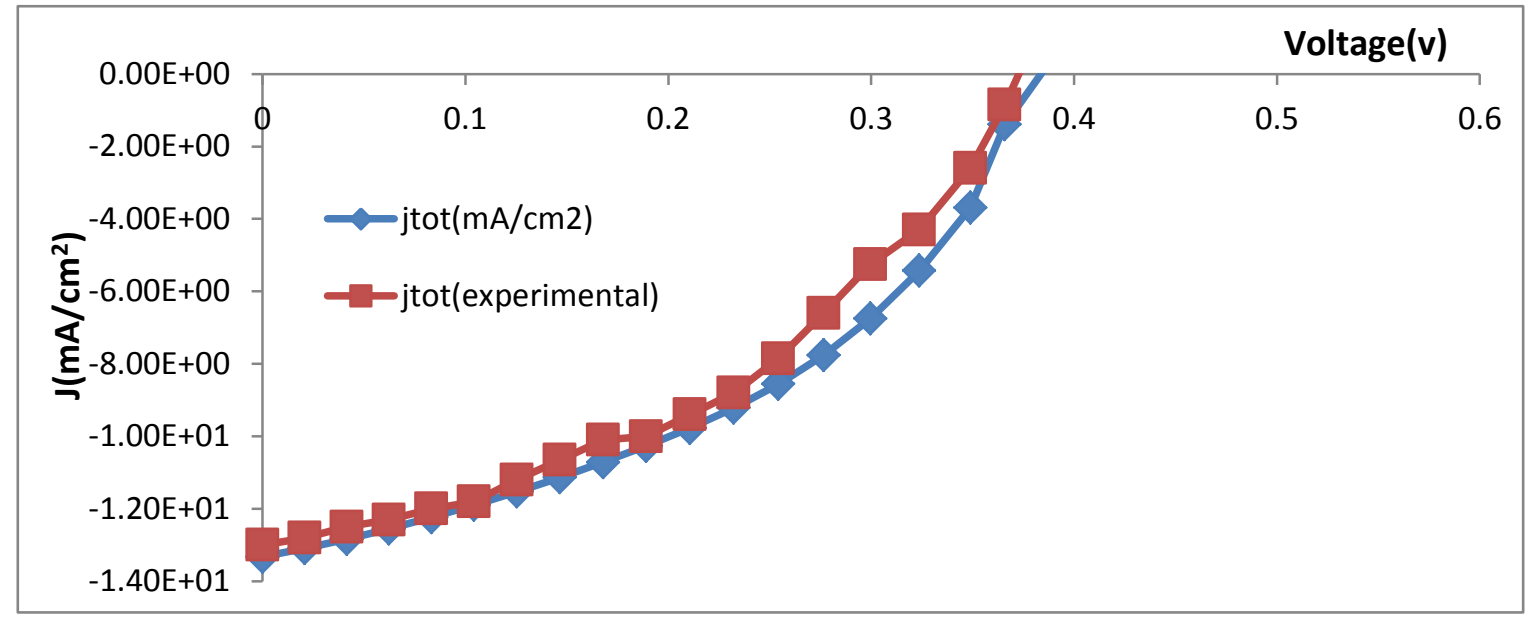

Figure 2-I-V curve for experimental and theoretical work.

\subsection{Effects of absorption layer}

\subsubsection{Concentration of Accepter $\left(\mathbf{N}_{\mathrm{A}}\right)$}

After comparing the theoretical and the experimental results, we attempted to improve cell output parameters of ITO/ZnO/CdS/CZTS by increasing the concentration of accepter for the CZTS layer from $10^{13} \mathrm{~cm}^{-3}$ to $10^{19} \mathrm{~cm}^{-3}$. The results revealed an increase in $\mathrm{FF}, \mathrm{V}_{\mathrm{oc}}$, and $\eta$ values and a decrease in $\mathbf{J}_{\mathrm{sc}}$, as shown in Figure-3. The increase of the carrier density caused a decrease in the saturation current of the device, consequently resulting in an increase in $\mathrm{V}_{\text {oc }}$, according to equations 7 and 8 . The value of $\mathbf{J}_{\mathrm{sc}}$ decreased due to the higher carrier densities, according to equation (9). will boost the recombination process and reduce the probability of the collection of the photo generated electrons [18]. The photons of longer wavelength have less energy and are deeply absorbed in the CZTS layer. Thus, the collected conversion efficiency is more dependent on the influence of concentration density, where we found the best concentration to be $10^{18} \mathrm{~cm}^{-3}$.

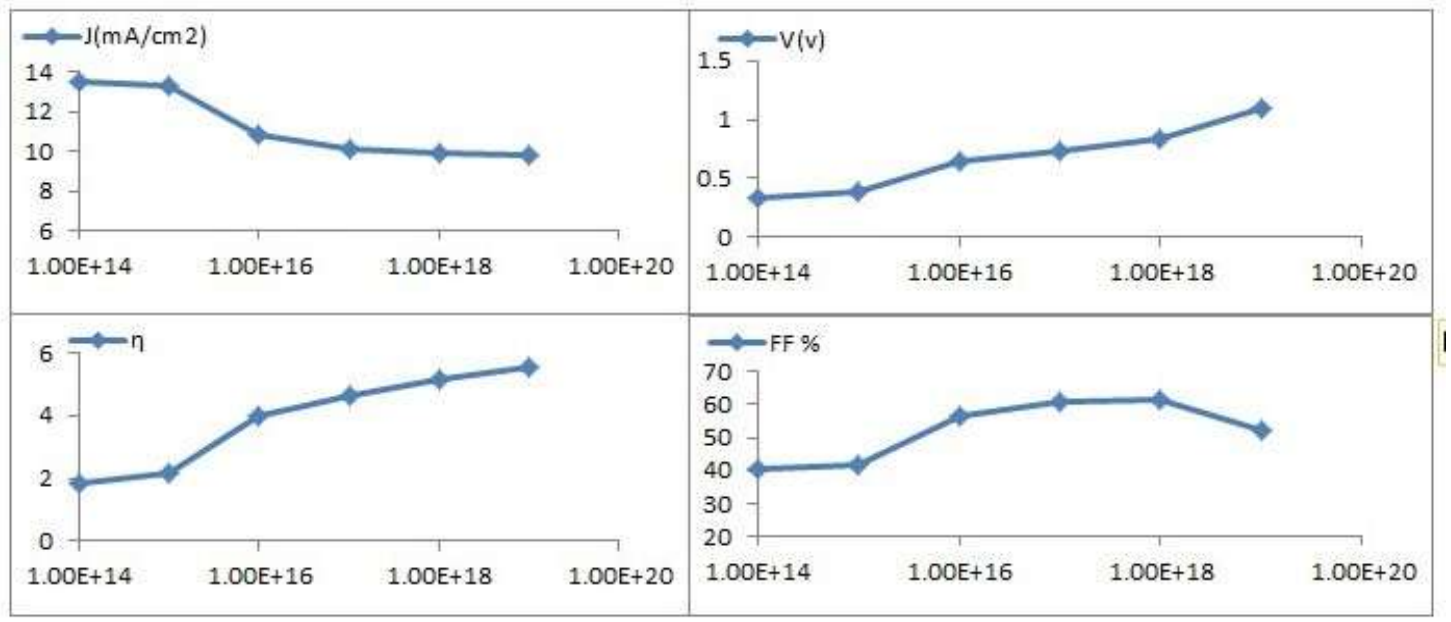

Accepter CZTS layer $\mathrm{N}_{\mathrm{A}}\left(\mathrm{cm}^{-3}\right)$

Figure 3-Concentration of accepter for the absorption layer as a function of cell parameters. 


\subsubsection{Thickness $\left(\mathbf{W}_{\text {thickness }}\right)$}

The thickness of the CZTS absorption layer was changed while maintaining all other cell parameters stable. Note from Figure- 4 that the increase in the thickness leads to an increase in $V_{\mathrm{oc}}, \eta$, and $J_{\mathrm{sc}}$. As for the filling factor, it increases to a certain value and then decreases. These effects of changing absorber thickness on conversion efficiency of the cell are due to the fact that the number of the absorbed photons depends on both the thickness and absorption coefficient of the absorber. This is shown in the following equation:

$$
a(\lambda, \mathrm{W})=1-\exp (-2(\lambda) W)
$$

where $\mathrm{W}$ is thickness of the cell and $(\lambda)$ is absorption of the cell with a wavelength of $\lambda$. The increase in thickness leads to the absorption of photons that have less energy than that of the energy gap [7]. The best absorption layer thickness was found to be $0.9 \mu \mathrm{m}$.

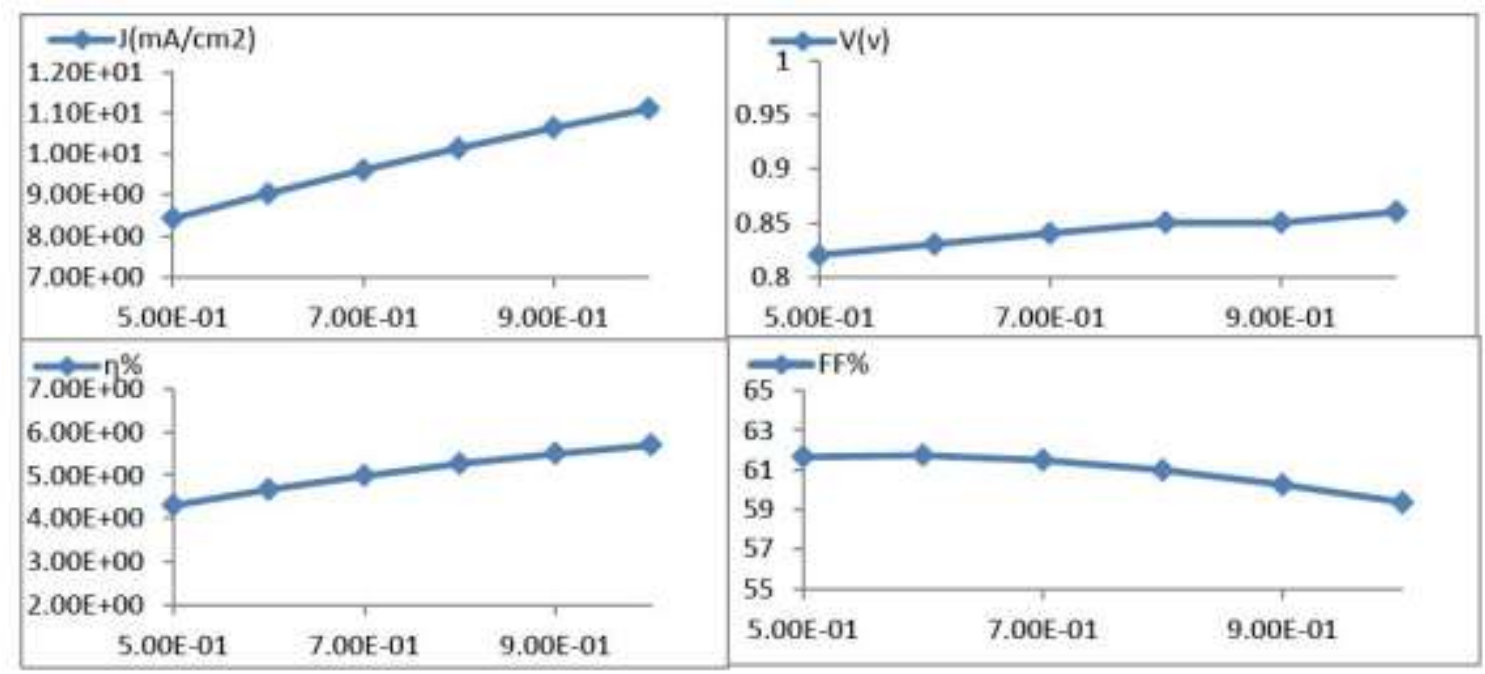

Thickness CZTS layer W $(\mu \mathrm{m})$

Figure 4-Thickness of the absorption layer as a function of cell parameters.

\subsection{Effects of $N_{D}$ window layer}

The buffer layer (CdS) and the first window layer (ITO) did not show any change of cell parameters when changing the thickness values and their donors. Thus, we made a change of donor concentration for the second window layer $(\mathrm{ZnO})$. Figure-5 shows that the increase in concentration leads to an increase in $\mathrm{V}_{\mathrm{oc}}$ and $\eta$. As for the filling factor and short circuit current, they remained constant, while the best concentration of the window layer was $10^{21} \mathrm{~cm}^{-3}$, because the increase in donors leads to a decrease in saturation current and an increase in open circuit voltage, which increases the performance of the cell [19]. Upon changing the thickness of the window layer, there was no improvement in the cell.

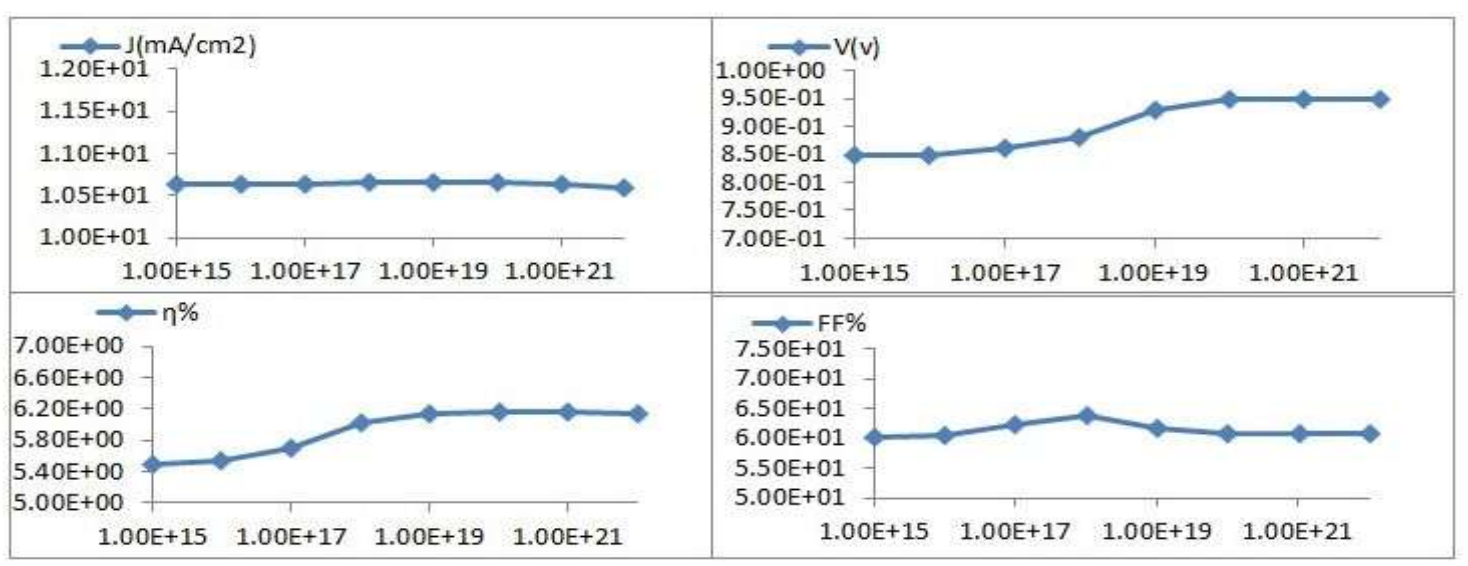

Donor $\mathrm{ZnO}$ layer $\mathrm{N}_{\mathrm{D}}\left(\mathrm{cm}^{-3}\right)$

Figure 5-Donor concentration of window layer as a function of cell parameter. 


\subsection{Comparing the theoretical cell with the cell after improvement}

Through the previous figures, the concentration of receptors and thicknesses values for the absorption layer were selected to be $10^{18} \mathrm{~cm}^{-3}$ and $0.9 \mu \mathrm{m}$, respectively, while the concentration of the donor was $10^{21} \mathrm{~cm}^{-3}$, and thus the cell became well characterized. Figure-6 shows an increase in voltages after improvements and a decrease in current. The reason for this is the increase in the concentration of doping, which is shown according to the equations 6, 7, and 8. Also, we increased the thickness of the absorption layer, which led to an increase in the absorption of photons and an increase in the generation of electron-hole pairs [19]. Figure-6 shows the I-V curve I-V properties of the theoretical cell and the cell after improvement. Table -3 shows the theoretical cell parameters of the cell after improvement.

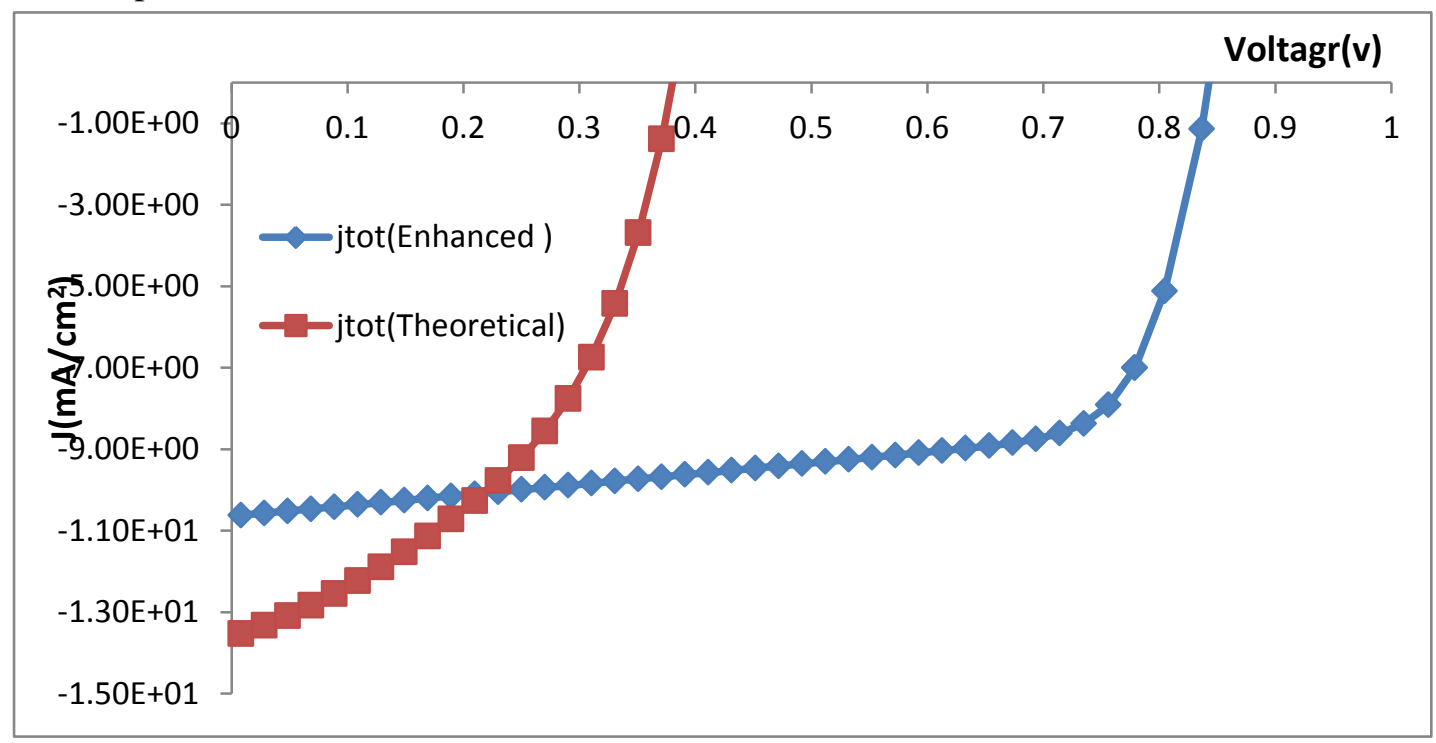

Figure 6- I-V Relationship of the theoretical cell and the cell after improvement.

Table 3-Outputs for experimental and theoretical cells before and after improvement

\begin{tabular}{|l|c|c|c|c|c|}
\hline \multicolumn{1}{|c|}{$\mathrm{S}$} & cell structure & $\mathrm{V}(\mathrm{v})$ & $\mathrm{J}\left(\mathrm{mA} / \mathrm{cm}^{2}\right)$ & $\mathrm{FF} \%$ & $\eta \%$ \\
\hline 1. & $\mathrm{ITO} / \mathrm{ZnO} / \mathrm{CdS} / \mathrm{CZTS}$ ( Experimental) & 0.37 & 13.14 & 37.9 & 1.93 \\
\hline 2. & ITO/ZnO/CdS/CZTS ( Theoretical) & 0.38 & 13.32 & 41.92 & 2.18 \\
\hline 3. & ITO/ZnO/CdS/CZTS (After optimization) & 0.84 & 10.64 & 68.63 & 6.17 \\
\hline
\end{tabular}

\section{3-5- Back surface layer}

To increase the efficiency of the improved cell (ITO / ZnO / CdS / CZTS), we will add the different layers of the back reflection with the constancy of the parameters of all other layers, which are $\mathrm{Si}$, CIGS CZTS, CMTS, CZTSSe, and $\mathrm{CuSdS}_{2}$. The addition of a suitable BSL helps in reversing the photons coming from the absorption layer and increasing the charge concentration. It also reduces the recombination and, thus, the connection becomes more ohmic [20]. Table-4 shows BSL parameters, where the best BSL was shown to be the CZTSSe, due to the low energy gap which reduces the height of the potential barrier and reduces the recombination of minority carriers upon back contact [15].Figure-7 shows the height of the potential barrier and Table-5 shows the outputs of the improved cell after adding the different reflection layers.

Table 4-The physical parameters of different BSL layers

\begin{tabular}{|c|c|c|c|c|c|c|c|c|}
\hline Parameters & $\begin{array}{l}\text { symbol } \\
\text { (unit) }\end{array}$ & $\begin{array}{l}\mathrm{SnS} \\
{[21]}\end{array}$ & $\begin{array}{c}\mathrm{Si} \\
{[22]}\end{array}$ & $\begin{array}{c}\text { CMT } \\
\text { S } \\
{[23]}\end{array}$ & CZTS & $\begin{array}{c}\text { CZTSS } \\
\mathrm{e} \\
{[21]}\end{array}$ & $\begin{array}{c}\mathrm{CuSb} \\
\mathrm{S}_{2} \\
{[26]}\end{array}$ & $\begin{array}{c}\text { CICS } \\
\text { [27] }\end{array}$ \\
\hline Band gap & Eg (ev) & 1.1 & 1.12 & 1.6 & $1.4[24]$ & 1 & 1.5 & 1.05 \\
\hline Electron affinity & $\chi(\mathrm{ev})$ & 4.2 & 4.05 & 4.35 & $4.5[24]$ & 4 & 4.5 & 4.14 \\
\hline
\end{tabular}




\begin{tabular}{|c|c|c|c|c|c|c|c|c|}
\hline Dielectric permittivity & $\varepsilon_{\mathrm{r}}$ & 12.5 & 11.9 & 9 & $9[24]$ & 13.6 & 10 & 10 \\
\hline $\begin{array}{c}\text { CB effective density of } \\
\text { states }\end{array}$ & $N_{C}\left(\mathrm{~cm}^{-3}\right)$ & $\begin{array}{c}1 \times \\
10^{19}\end{array}$ & $\begin{array}{r}258 \times \\
10^{19}\end{array}$ & $\begin{array}{l}2.2 \times \\
10^{18}\end{array}$ & $\begin{array}{l}2.2 \times \\
10^{18} \\
{[24]}\end{array}$ & $\begin{array}{l}22 \times \\
10^{18}\end{array}$ & $\begin{array}{l}2.2 \times \\
10^{18}\end{array}$ & $\begin{array}{l}1.0 \times \\
10^{18}\end{array}$ \\
\hline $\begin{array}{l}\text { VB effective density of } \\
\text { states }\end{array}$ & $N_{V}\left(\mathrm{~cm}^{-3}\right)$ & $\begin{array}{l}4.13 \\
\times 10^{19}\end{array}$ & $\begin{array}{l}2.65 \\
\times 10^{19}\end{array}$ & $\begin{array}{l}1.8 \times \\
10^{19}\end{array}$ & $\begin{array}{l}1.8 \times \\
10^{19} \\
{[24]}\end{array}$ & $\begin{array}{l}1.8 \times \\
10^{19}\end{array}$ & $\begin{array}{l}1.8 \times \\
10^{19}\end{array}$ & $\begin{array}{l}1.0 \times \\
10^{18}\end{array}$ \\
\hline $\begin{array}{l}\text { Electron thermal } \\
\text { velocity }\end{array}$ & $\mathrm{V}_{\mathrm{n}}(\mathrm{cm} / \mathrm{s})$ & $\begin{array}{l}1.0 \\
\times 10^{7}\end{array}$ & $\begin{array}{l}1.0 \\
\times 10^{7}\end{array}$ & $\begin{array}{r}1.0 \times \\
10^{7}\end{array}$ & $\begin{array}{c}1.0 \times \\
10^{7}\end{array}$ & $\begin{array}{r}1.0 \times \\
10^{7}\end{array}$ & $\begin{array}{r}1.0 \times \\
10^{7}\end{array}$ & $\begin{array}{r}1.0 \times \\
10^{7}\end{array}$ \\
\hline $\begin{array}{l}\text { Hole thermal } \\
\text { velocity }\end{array}$ & $\mathrm{V}_{\mathrm{P}}(\mathrm{cm} / \mathrm{s})$ & \begin{tabular}{l|}
1.0 \\
$\times 10^{7}$ \\
\end{tabular} & \begin{tabular}{l|}
1.0 \\
$\times 10^{7}$ \\
\end{tabular} & $\begin{array}{c}1.0 \times \\
10^{7} \\
\end{array}$ & $\begin{array}{c}1.0 \times \\
10^{7} \\
\end{array}$ & $\begin{array}{r}1.0 \times \\
10^{7} \\
\end{array}$ & $\begin{array}{r}1.0 \times \\
10^{7} \\
\end{array}$ & $\begin{array}{r}1.0 \times \\
10^{7} \\
\end{array}$ \\
\hline Electron mobility & $\begin{array}{c}\mu_{\mathrm{n}}\left(\mathrm{cm}^{2} / v .\right. \\
\mathrm{s})\end{array}$ & 25 & 1350 & 0.16 & $\begin{array}{c}100[15 \\
]\end{array}$ & 100 & 100 & 30 \\
\hline Hole mobility & $\mu_{\mathrm{p}}\left(\mathrm{cm}^{2} / v\right.$. & 100 & 450 & 0.16 & $25[15]$ & 25 & 25 & 15 \\
\hline $\begin{array}{c}\text { Shallow uniform donor } \\
\text { density }\end{array}$ & $\begin{array}{c}\mathrm{N}_{\mathrm{D}}\left(1 / \mathrm{cm}^{3}\right. \\
) \\
\end{array}$ & 0 & 0 & 0 & 0 & 0 & 0 & 0 \\
\hline $\begin{array}{l}\text { Shallow uniform } \\
\text { acceptor density }\end{array}$ & $\begin{array}{c}\mathrm{N}_{\mathrm{A}} \\
\left(1 / \mathrm{cm}^{3}\right)\end{array}$ & $\begin{array}{l}1.0 \\
\times 10^{14} \\
\end{array}$ & $\begin{array}{l}1.0 \times \\
10^{20}\end{array}$ & $\begin{array}{l}1.0 \times \\
10^{16}\end{array}$ & $\begin{array}{l}1.0 \times \\
10^{17}\end{array}$ & $\begin{array}{l}1.0 \times \\
10^{17}\end{array}$ & $\begin{array}{l}7.0 \times \\
10^{18}\end{array}$ & $\begin{array}{l}1.0 \times \\
10^{19}\end{array}$ \\
\hline
\end{tabular}

Table 5-Outputs of the improved cell add various layer back reflection.

\begin{tabular}{|c|c|c|c|c|c|}
\hline $\mathrm{S}$ & cell structure & $\mathrm{V}(\mathrm{v})$ & $\mathrm{J}\left(\mathrm{mA} / \mathrm{cm}^{2}\right)$ & FF\% & $\eta \%$ \\
\hline $1-$ & ITO/ZnO/CdS/CZTS Experimental & 0.37 & 13.14 & 37.9 & 1.93 \\
\hline $2-$ & ITO/ZnO/CdS/CZTS Theoretical & 0.38 & 13.32 & 41.92 & 2.18 \\
\hline $3-$ & ITO/ZnO/CdS/CZTS After optimization & 0.84 & 10.64 & 68.63 & 6.17 \\
\hline 4- & ITO/ZnO/CdS/CZTS/Si & 0.82 & 9.63 & 66.89 & 5.29 \\
\hline $5-$ & ITO/ZnO/CdS/CZTS/CIGS & 0.84 & 9.79 & 65.67 & 5.45 \\
\hline 6- & ITO/ZnO/CdS/CZTS/CZTS & 0.89 & 9.98 & 63.21 & 5.66 \\
\hline $7-$ & ITO/ZnO/CdS/CZTS/CMTS & 0.99 & 15.84 & 62.1 & 9.77 \\
\hline $8-$ & $\underline{\mathrm{ITO} / \mathrm{ZnO} / \mathrm{CdS} / \mathrm{CZTS} / \mathrm{CZTSSe}}$ & $\underline{0.76}$ & $\underline{26.19}$ & 70.07 & $\underline{13.99}$ \\
\hline 9- & ITO/ZnO/CdS/CZTS/SnS & 1.8 & 10.5 & 33.89 & 6.41 \\
\hline $10-$ & ITO/ZnO/CdS/CZTS/CuSbS ${ }_{2}$ & 0.98 & 13.74 & 61.68 & 8.31 \\
\hline
\end{tabular}

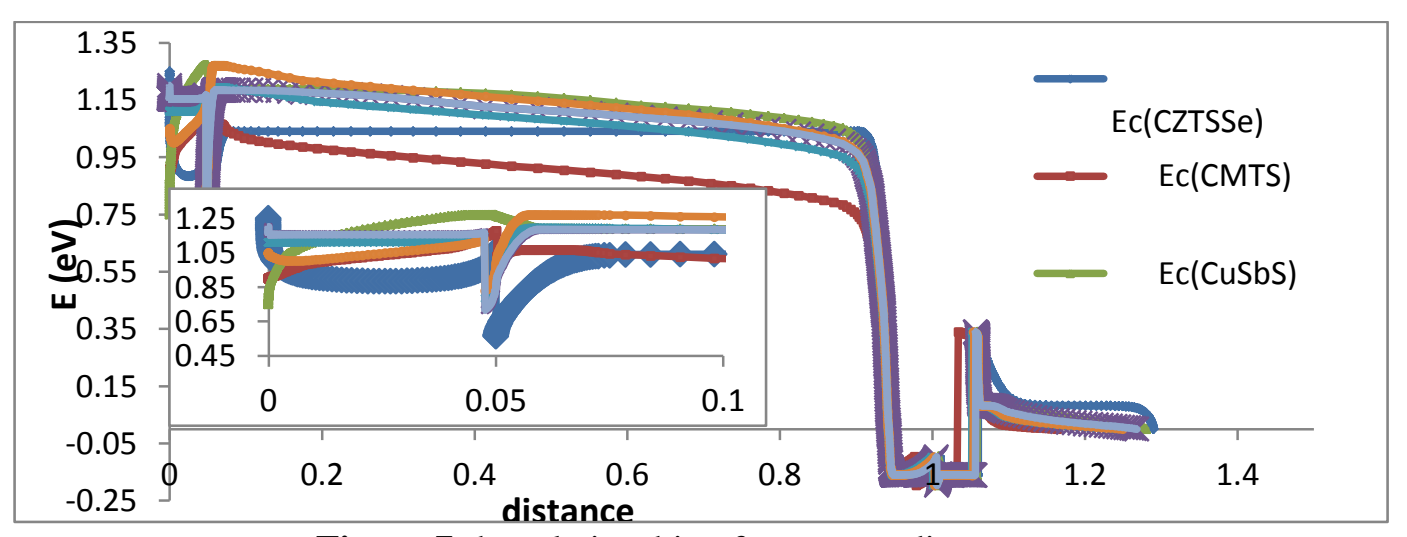

Figure 7-the relationship of energy to distance.

\subsection{Effects of buffer layer}

Various buffer layers were added to the cell after the improvement of ITO / ZnO / CZTS with keeping the parameters of the other cell layers stable and the removal of the buffer layer (CdS). Hence, 
the change will only be in the buffer layer in terms of layer type and concentration of doping. Also, the buffer layer concentration increases the photons access to the absorption layer due increased homogeneity between the window layer and absorption [28]. It turned out to have a significant effect on the parameter of the cell due to the large difference in the energy gap between the absorption layer and the window layer. The components of the added buffer layer consist of $\mathrm{TiO}_{2}, \mathrm{In}_{2} \mathrm{~S}_{3}, \mathrm{PCBM}$, $\mathrm{CdSe}, \mathrm{SnS}_{2}, \mathrm{~V}_{2} \mathrm{O}_{5}$, and CdS. The best buffer layer was the CdSe. The large electron affinity causes the placement of the edge conduction band of the buffer layer near the edge valence band of the absorption layer. Hence, it will allow the passage of photons to the absorption layer, which increases its efficiency. As a result, large quantum efficiency will be gained. Table- 6 shows the main parameters of the buffer layer and Table-7 shows the results obtained when adding the different buffer layers to the cell after improvement.

Table 6- Main parameters of the buffer layer added to the cell after improvement.

\begin{tabular}{|c|c|c|c|c|c|c|c|c|}
\hline Parameters & $\begin{array}{c}\text { symbol } \\
\text { unit })\end{array}$ & $\begin{array}{c}\mathrm{TiO}_{2} \\
{[29]}\end{array}$ & $\begin{array}{l}\mathrm{In}_{2} \mathrm{~S}_{3} \\
{[26]}\end{array}$ & $\begin{array}{l}\mathrm{V}_{2} \mathrm{O}_{5} \\
{[30]}\end{array}$ & $\begin{array}{c}\mathrm{CdO} \\
{[30]}\end{array}$ & $\begin{array}{c}\mathrm{CdSe} \\
{[31]}\end{array}$ & $\begin{array}{c}\mathrm{SnS}_{2} \\
{[32]}\end{array}$ & $\begin{array}{c}\mathrm{PCBM} \\
{[33]}\end{array}$ \\
\hline Band gap & $\mathrm{Eg}(\mathrm{ev})$ & 2.26 & 2.1 & 2.3 & 2.28 & 1.75 & 2.38 & 2.1 \\
\hline Electron affinity & $\chi(\mathrm{ev})$ & 4.2 & 4.7 & 3.99 & 4.5 & 4.95 & 4.16 & 3.9 \\
\hline $\begin{array}{c}\text { Dielectric } \\
\text { permittivity }\end{array}$ & $\varepsilon_{\mathrm{r}}$ & 10 & 13.5 & 4.28 & 5.3 & 10.6 & 10 & 3.9 \\
\hline $\begin{array}{c}\text { CB effective } \\
\text { density of states }\end{array}$ & $\mathrm{N}_{\mathrm{C}}\left(\mathrm{cm}^{-3}\right)$ & $\begin{array}{l}2.0 \\
\times 10^{17}\end{array}$ & $\begin{array}{l}1.8 \\
\times 10^{19}\end{array}$ & $\begin{array}{l}2.2 \\
\times 10^{18}\end{array}$ & $\begin{array}{l}2.2 \\
\times 10^{18}\end{array}$ & $\begin{array}{l}2.2 \\
\times 10^{18}\end{array}$ & $\begin{array}{l}2.2 \\
\times 10^{18}\end{array}$ & $\begin{array}{l}2.2 \\
\times 10^{19}\end{array}$ \\
\hline $\begin{array}{c}\text { VB effective } \\
\text { density of states }\end{array}$ & $\mathrm{N}_{\mathrm{V}}\left(\mathrm{cm}^{-3}\right)$ & $\begin{array}{l}6.0 \\
\times 10^{17}\end{array}$ & $\begin{array}{l}4.0 \\
\times 10^{13}\end{array}$ & $\begin{array}{l}1.8 \\
\times 10^{19}\end{array}$ & $\begin{array}{l}1.8 \\
\times 10^{19}\end{array}$ & $\begin{array}{l}1.8 \\
\times 10^{19}\end{array}$ & $\begin{array}{l}1.8 \\
\times 10^{19}\end{array}$ & $\begin{array}{l}2.2 \\
\times 10^{19}\end{array}$ \\
\hline $\begin{array}{c}\text { Electron thermal } \\
\text { velocity }\end{array}$ & $\mathrm{V}_{\mathrm{n}}\left(\mathrm{cm}^{2}\right)$ & $\begin{array}{l}1.0 \\
\times 10^{7}\end{array}$ & $\begin{array}{l}1.0 \\
\times 10^{7}\end{array}$ & $\begin{array}{l}1.0 \\
\times 10^{7}\end{array}$ & $\begin{array}{l}1.0 \\
\times 10^{7}\end{array}$ & $\begin{array}{l}1.0 \\
\times 10^{7}\end{array}$ & $\begin{array}{l}1.0 \\
\times 10^{7}\end{array}$ & $\begin{array}{l}1.0 \\
\times 10^{7}\end{array}$ \\
\hline $\begin{array}{c}\text { Hole thermal } \\
\text { velocity }\end{array}$ & $\mathrm{V}_{\mathrm{P}}\left(\mathrm{cm}^{2}\right)$ & $\begin{array}{l}1.0 \\
\times 10^{7}\end{array}$ & $\begin{array}{l}1.0 \\
\times 10^{7}\end{array}$ & $\begin{array}{l}1.0 \\
\times 10^{7}\end{array}$ & $\begin{array}{l}1.0 \\
\times 10^{7}\end{array}$ & $\begin{array}{l}1.0 \\
\times 10^{7}\end{array}$ & $\begin{array}{l}1.0 \\
\times 10^{7}\end{array}$ & $\begin{array}{l}1.0 \\
\times 10^{7}\end{array}$ \\
\hline Electron mobility & $\mu_{\mathrm{n}}\left(\mathrm{cm}^{2} / \mathrm{v} . \mathrm{s}\right)$ & 100 & 400 & 1.26 & 146 & 100 & 5 & 0.001 \\
\hline Hole mobility & $\mu_{\mathrm{p}}\left(\mathrm{cm}^{2} / \mathrm{v} . \mathrm{s}\right)$ & 25 & 210 & 34.5 & 39.5 & 25 & 5 & 0.002 \\
\hline $\begin{array}{c}\text { Shallow uniform } \\
\text { donor density }\end{array}$ & $\mathrm{N}_{\mathrm{D}}\left(1 / \mathrm{cm}^{3}\right)$ & $\begin{array}{l}1.0 \\
\times 10^{17}\end{array}$ & $\begin{array}{l}1.0 \\
\times 10^{22}\end{array}$ & $\begin{array}{l}1.0 \\
\times 10^{19}\end{array}$ & $\begin{array}{l}1.0 \\
\times 10^{20}\end{array}$ & $\begin{array}{l}1.0 \\
\times 10^{22}\end{array}$ & $\begin{array}{l}1.0 \\
\times 10^{18}\end{array}$ & $\begin{array}{l}1.0 \\
\times 10^{19}\end{array}$ \\
\hline $\begin{array}{c}\text { Shallow uniform } \\
\text { acceptor density }\end{array}$ & $\mathrm{N}_{\mathrm{A}}\left(1 / \mathrm{cm}^{3}\right)$ & 0 & 0 & 0 & 0 & 0 & 0 & 0 \\
\hline
\end{tabular}

Table 7-Outputs of the improved cell after adding various layers buffer

\begin{tabular}{|l|c|c|c|c|c|}
\hline \multicolumn{1}{|c|}{$\mathrm{S}$} & cell structure & $\mathrm{V}(\mathrm{v})$ & $\mathrm{J}\left(\mathrm{mA} / \mathrm{cm}^{2}\right)$ & $\mathrm{FF} \%$ & $\eta \%$ \\
\hline 1. & $\mathrm{ITO} / \mathrm{ZnO} / \mathrm{TiO}_{2} / \mathrm{CZTS}$ & 1.0 & 13.78 & 60.55 & 8.38 \\
\hline 2. & $\mathrm{ITO} / \mathrm{ZnO} / \mathrm{In}_{2} \mathrm{~S}_{3} / \mathrm{CZTS}$ & 0.85 & 15.71 & 72.29 & 9.69 \\
\hline 3. & $\mathrm{ITO} / \mathrm{ZnO} / \mathrm{PCBM} / \mathrm{CZTS}$ & 0.83 & 6.35 & 59.89 & 3.19 \\
\hline 4. & $\underline{\mathrm{ITO} / \mathrm{ZnO} / \mathrm{CdSe} / \mathrm{CZTS}}$ & $\underline{0.85}$ & $\underline{21.41}$ & $\underline{73.42}$ & $\underline{13.48}$ \\
\hline 5. & $\mathrm{ITO} / \mathrm{ZnO} / \mathrm{SnS}_{2} / \mathrm{CZTS}$ & 0.99 & 13.0 & 60.71 & 7.83 \\
\hline 6. & $\mathrm{ITO} / \mathrm{ZnO} / \mathrm{V}_{2} \mathrm{O}_{5} / \mathrm{CZTS}$ & 0.93 & 8.62 & 59.02 & 4.78 \\
\hline 7. & $\mathrm{ITO} / \mathrm{ZnO} / \mathrm{CdO} / \mathrm{CZTS}$ & 1.0 & 13.74 & 60.49 & 8.34 \\
\hline
\end{tabular}

\subsection{Combining the best buffer layer with different reflection layers}

We took the best buffer layer (CdSe) with the different layers of the reflection back, then we inserted them into the improved cell. As shown in Table-8, it appears that the best of these cells was 
ITO / ZnO / CdSe / CZTS / CZTSSe. We observe that the best back reflection layer is CZTSSe, which was combined with the best buffer layer $(\mathrm{CdSe})$ to form the best cell obtained by the present study. Table-8 explains the parameters of cells.

Table 8-Outputs of the solar cell after adding the various BSL with the CdSe Buffer layer.

\begin{tabular}{|l|c|c|c|c|c|}
\hline \multicolumn{1}{|c|}{$\mathrm{S}$} & Cell structure & $\mathrm{V}(\mathrm{v})$ & $\mathrm{J}\left(\mathrm{mA} / \mathrm{cm}^{2}\right)$ & $\mathrm{FF} \%$ & $\%$ \\
\hline 1. & $\mathrm{ITO} / \mathrm{ZnO} / \mathrm{CdSe} / \mathrm{CZTS} / \mathrm{Si}$ & 0.85 & 21.08 & 70.29 & 12.73 \\
\hline 2. & $\mathrm{ITO} / \mathrm{ZnO} / \mathrm{CdSe} / \mathrm{CZTS} / \mathrm{CIGS}$ & 0.9 & 21.2 & 67.78 & 12.97 \\
\hline 3. & $\mathrm{ITO} / \mathrm{ZnO} / \mathrm{CdSe} / \mathrm{CZTS} / \mathrm{CZTS}$ & 0.95 & 21.22 & 64.67 & 13.14 \\
\hline 4. & $\mathrm{ITO} / \mathrm{ZnO} / \mathrm{CdSe} / \mathrm{CZTS} / \mathrm{CMTS}$ & 1.04 & 22.95 & 60.14 & 14.14 \\
\hline 5. & $\underline{\mathrm{ITO} / \mathrm{ZnO} / \mathrm{CdSe} / \mathrm{CZTS} / \mathrm{CZTSSe}}$ & $\underline{0.76}$ & $\underline{30.86}$ & $\underline{69.83}$ & $\underline{16.53}$ \\
\hline 6. & $\mathrm{ITO} / \mathrm{ZnO} / \mathrm{CdSe} / \mathrm{CZTS} / \mathrm{CuSbS}_{2}$ & 0.87 & 21.43 & 69.29 & 13.02 \\
\hline
\end{tabular}

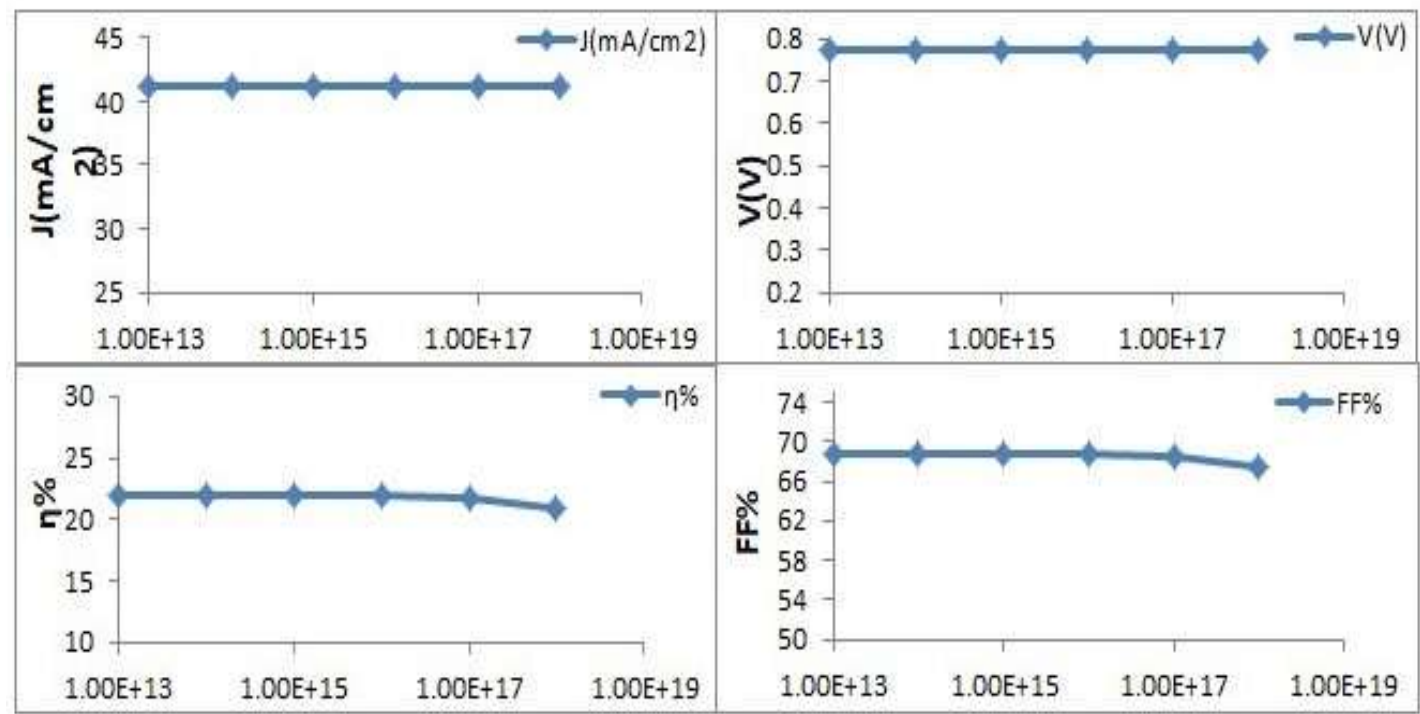

Accepter CZTS layer $\mathrm{N}_{\mathrm{A}}\left(\mathrm{cm}^{-3}\right)$

Figure 8-Reflection layer thickness as a function of cell outputs.

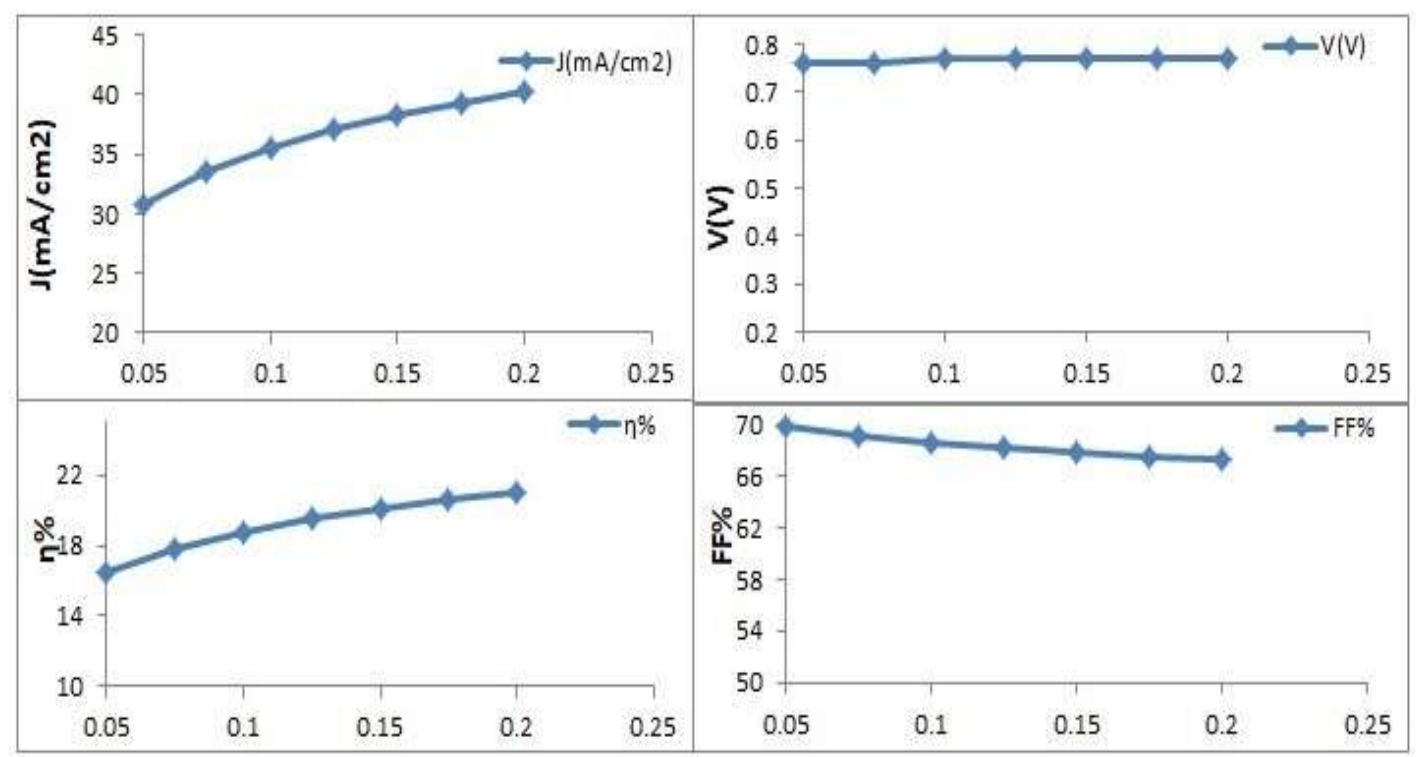

Thickness CZTSSe layer W( $\mu \mathrm{m})$

Figure 9-Concentration of the absorption layer as a function of cell outputs.

\subsection{Comparison of cells}

After obtaining the most efficient cell, we attempted to improve it by changing all parameters of the layers in terms of thickness and the concentration of doping. It was found that the concentration of 
the accepter for the absorption layer $\left(\mathrm{N}_{\mathrm{A}}\right)$ and the thickness of the back reflection layer only affect the performance of the cell. When we increase the thickness of the BSL layer from $0.05 \mu \mathrm{m}$ to $0.2 \mu \mathrm{m}$, as shown in Figure-8, an increase in the values of $\eta$ and Jsc and a decrease in FF were observed. As for the open circuit voltage, it remained constant, and the reason, as we showed previously, is to increase the electrons that return back to the absorption layer by increasing the thickness. When the doping concentration of the absorption layer was increased from $10^{13} \mathrm{~cm}^{-3}$ to $10^{19} \mathrm{~cm}^{-3}$, as shown in Figure -9, we noticed an increase in the conversion efficiency to $10^{17} \mathrm{~cm}^{-3}$. As for the filling factor, it was only slightly decreased, where the voltage and current were about constant. Thus, the efficiency was enhanced from $16.53 \%$ to $21.87 \%$. Table- 9 shows a comparison of the experimental cell with the theoretical cell and the cell after improvement. It shows the best cells obtained after adding reflection and buffer layers and combining them to achieve the best cell. Figure-10 shows the I-V curves for all cells.

Table 9-Outputs of the experimental and theoretical cells and cell after improvement, with the best results obtained from the study.

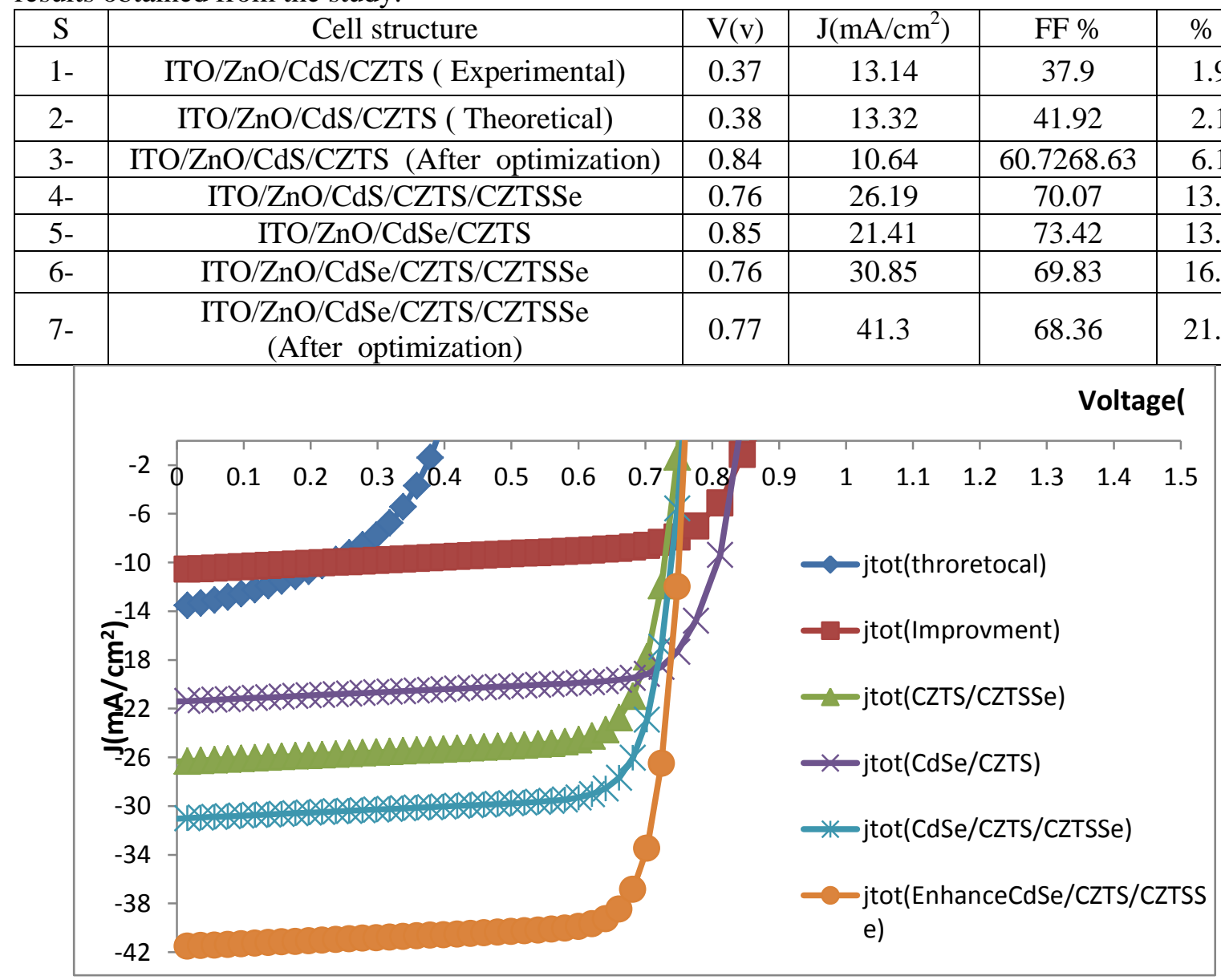

Figure 10- I-V Curves for all studied cells.

\subsection{Quantum Efficiency (QE)}

Quantum efficiency is the number of electron-hole pairs generated due to the fall of light on the diode. Figure-11 shows the quantum efficiency and its relationship to the wavelength of the best cells obtained. The first cell is the theoretical cell obtained from simulation. It appears that the quantum efficiency value starts with approximately $60 \%$ at the wavelength $100 \mathrm{~nm}$ and then begins to decrease rapidly to reach zero value at $355 \mathrm{~nm}$. The reason is that the value of the absorption coefficient is high at short wavelengths absorption and occupies a short recombination time near the surface, which leads the generated carriers to return and unite before trapping them at the p-n junction [34]. Thereafter, the value starts to sharply fall until the zero value due to the recombination of the front surface [35]. The second cell after improvement had quantum efficiency of 52\% at $100 \mathrm{~nm}$, which increases until it 
reached $92 \%$ at $375 \mathrm{~nm}$, then started to gradually decrease until it reached zero at $850 \mathrm{~nm}$. The reason is the low propagation length and reflectivity. In addition, the absorption becomes zero at long wavelengths because the quantum efficiency is inversely proportional to the wavelength, according to the relationship $\mathrm{Q}_{\mathrm{E}}=1.24 \frac{\mathrm{R}_{\lambda}}{\lambda} \mathrm{R}_{\lambda}$ (W/A) [29]. The third case was when adding a layer of BSL, where the efficiency was $52 \%$ at wavelength of $100 \mathrm{~nm}$ and then increased until it reaches $98 \%$ at $370 \mathrm{~nm}$, then started gradually to decrease reaching zero at $1250 \mathrm{~nm}$. For the fourth case, when there was a buffer layer, the quantum efficiency was $52 \%$ at $100 \mathrm{~nm}$ and then increased until it reached $100 \%$ at $350 \mathrm{~nm}$. Then, it was stabilized at up to $700 \mathrm{~nm}$ and began to very sharply decrease at up to $720 \mathrm{~nm}$. The cause of this deficiency was the boundary of the energy gap of the absorbent layer. It then began to gradually drop to zero at $850 \mathrm{~nm}$, because the the energy gap areas started to enter the other layers. The fifth case was when there were two layers of reflection and buffer, where the quantum efficiency was $52 \%$ at $100 \mathrm{~nm}$. The value increased until it reached $100 \%$ at $350 \mathrm{~nm}$, then stabilized until 710 $\mathrm{nm}$. Then it started with a sharp fall of two phases at $710 \mathrm{~nm}$ and at $850 \mathrm{~nm}$, followed by a gradual decrease until it reached zero at $1250 \mathrm{~nm}$.The most efficient cell was achieved in the sixth case, because it started at wavelength of $100 \mathrm{~nm}$ with an absorption of 52\%, then increased until it reached $100 \%$ at $350 \mathrm{~nm}$. Thereafter, the value was stabilized at up to $720 \mathrm{~nm}$ and then began to gradually decrease until it reached zero at $1250 \mathrm{~nm}$.

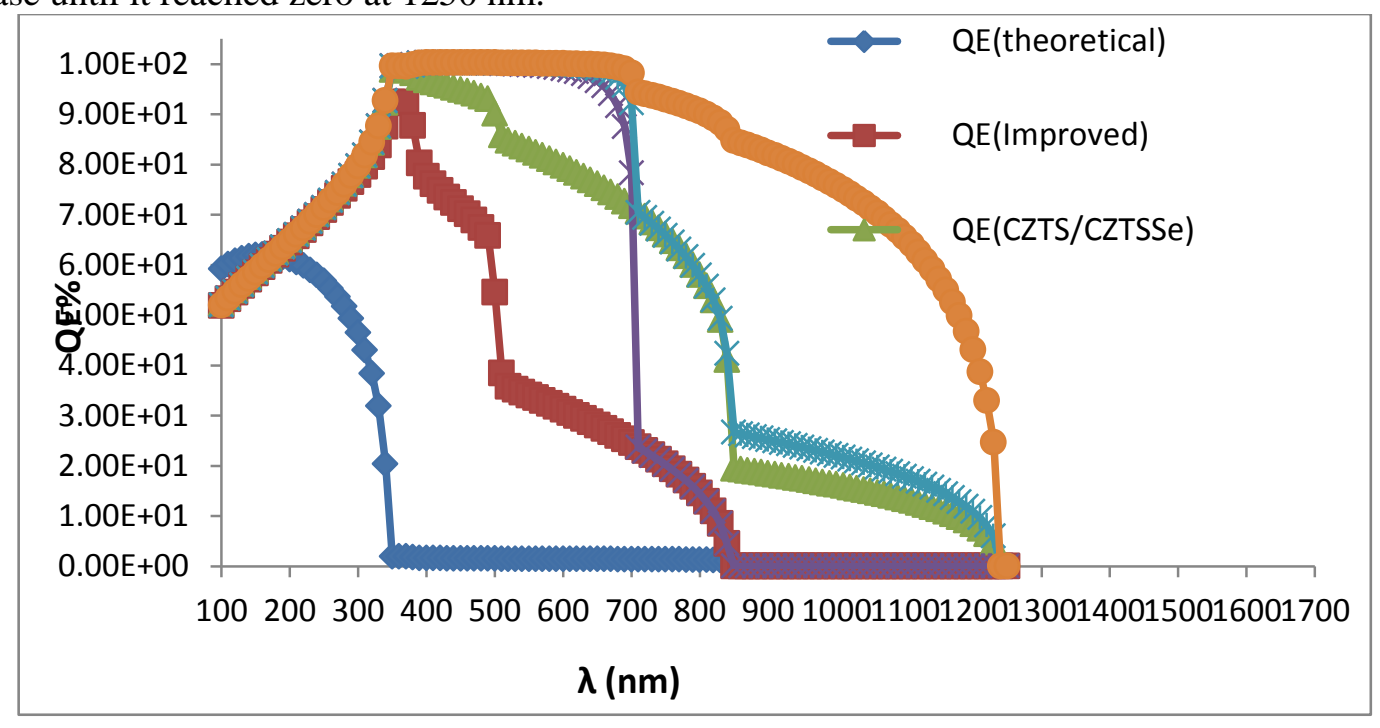

Figure 11-Wavelength relation with quantum efficiency.

\section{Conclusions}

The ITO / ZnO / CdS / CZTS cell was simulated by the SCAPS program and compared with an experimental cell after entering all the parameters form this research. We have completed the comparison by results from other researches and found a very large convergence between the experimental and theoretical work, where the defects increased the symmetry of the two works. Then, the theoretical cell was improved by increasing the doping concentration and thickness of the absorption layer and increasing the doping concentration of the window layer, which increased the cell efficiency. Then, we added BSL to the cell and increased the efficiency because the back reflection layer reduced the recombination at the back surface, This was due to the high potential barrier was added buffer layer increasing the efficiency of the cell because it allowed the photons to pass through to the absorption layer. Then we inserted the best reflection layer with the best buffer layer in the optimized cell and made a second improvement, which also increased the efficiency from $16.53 \%$ to $21.76 \%$.

\section{Acknowledgements}

The research was supported and reviewed by the Scientific Committee of the Department of Physics, College of Education for Pure Sciences, Tikrit University. 


\section{References}

1. Skhouni, O., El Manouni, A., Bayad, H. and Mari, B. 2017. Boosting the Performance of Solar Cells with Intermediate Band Absorbers The Case of ZnTe: O. Journal of Energy and Power Engineering, 11: 417-426.

2. Djinkwi Wanda, M., Ouédraogo, S., Tchoffo, F., Zougmoré, F., \& Ndjaka, J. M. B. 2016. Numerical investigations and analysis of $\mathrm{Cu} 2 \mathrm{ZnSnS4}$ based solar cells by SCAPS1D. International Journal of Photoenergy., Article ID 2152018, 9 pages http://dx.doi. org/10.1155 /2016/2152018.

3. Simya, O.K., Selvam, M., Karthik, A. and Rajendran, V. 2014. Dye-sensitized solar cells based on visible-light-active TiO2 heterojunction nanoparticles. Synthetic metals, 188: 124-129.

4. Sarkar, S., Howli, P., Ghorai, U.K., Das, B., Samanta, M., Das, N.S. and Chattopadhyay, K.K. 2018. Flower-like $\mathrm{Cu} 2 \mathrm{NiSnS} 4$ microspheres for application as electrodes of asymmetric supercapacitors endowed with high energy density. CrystEngComm, 20(10): 1443-1454.

5. Benami, A. 2019. Effect of CZTS Parameters on Photovoltaic Solar Cell from Numerical Simulation. Journal of Energy and Power Engineering., 13: 32-36.

6. Belalem, A. and Sandali, W. 2016. Simulation d'une cellule solaire photovoltaïque à base de $\mathrm{Cu} 2 \mathrm{ZnSn}$ (S, Se) 4.( Master Thesis). Department of Electrical Engineering، Faculty of Applied Sciences، UNIVERSITE CASE UNDER OUARGLA. Algeria.

7. Baig, F. 2019. Numerical analysis for efficiency enhancement of thin film solar cells. Institute of Design and Fabrication. (Doctoral dissertation). Design Institute for Automated Manufacturing and Production, Higher Technical School of Design Engineering, Polytechnic University of Valencia. Spain.

8. Skhouni, O., El Manouni, A., Mari, B. and Ullah, H. 2016. Numerical study of the influence of ZnTe thickness on CdS/ZnTe solar cell performance. The European Physical Journal Applied Physics., 74(2): 24602.

9. Hameed, K.Y., Faisal, B., Hanae, T., Marí, S.B., Saira, B. and Kaim, K.N.A. 2019. Modelling of novel-structured copper barium tin sulphide thin film solar cells. Bulletin of Materials Science., 42(5): 231.

10. Ganvir, R. 2016. Modelling of the nanowire CdS-CdTe device design for enhanced quantum efficiency in Window-absorber type solar cells.( Master Thesis). Department Electrical Engineering. College of Engineering .University of Kentucky. USA.

11. Michaelson, H.B. 1977. The work function of the elements and its periodicity . Journal of applied physics, 48(11): 4729-4733.

12. Guo, H., Li, Y., Guo, X., Yuan, N. and Ding, J. 2018. Effect of silicon doping on electrical and optical properties of stoichiometric Cu2ZnSnS4 solar cells. Physica B: Condensed Matter, 531: 915.

13. Rafee Mahbub, M., Islam, S., Anwar, F., Satter, S. S. and Ullah, S. M. 2016. Simulation of CZTS thin film solar cell for different buffer layers for high efficiency performance. South Asian Journal of Engineering and Technology, 2(52): 1-10.

14. Nichterwitz, M., Caballero, R., Kaufmann, C. A., Schock, H. W. and Unold, T. 2013. Generationdependent charge carrier transport in $\mathrm{Cu}$ (In, Ga) Se2/CdS/ZnO thin-film solar-cells. Journal of Applied Physics, 113(4): 044515.

15. Khattak, Y. H., Baig, F., Toura, H., Ullah, S., Marí, B., Beg, S. and Ullah, H. 2018. Effect of CZTSe BSF and minority carrier life time on the efficiency enhancement of CZTS kesterite solar cell. Current Applied Physics, 18(6): 633-641.

16. Mebarkia, C., Dib, D., Zerfaoui, H. and Belghit, R. 2016. Energy efficiency of a photovoltaic cell based thin films CZTS by SCAPS. Journal of Fundamental and Applied Sciences, 8(2): 363-371.

17. Seck, S. M., Ndiaye, E. N., Fall, M. and Charvet, S. 2020. Study of Efficiencies CdTe/CdS Photovoltaic Solar Cell According to Electrical Properties by Scaps Simulation. Natural Resources, 11(4): 147-155.

18. Khattak, Y. H. 2019. Modeling of high power conversion efficiency thin film solar cells. Institute of Design and Fabrication. (Doctoral dissertation). Design Institute for Automated Manufacturing and Production, Higher Technical School of Design Engineering, Polytechnic University of Valencia. Spain. 
19. Crane .A. M.' translation by Hassan . Y. M. 1989. Solar Cells Principles of Work, Technology and System Applications. Book House for Printing and Publishing. University of Mosul. Iraq. (in Arabic).

20. Mebarkia, C., Dib, D., Zerfaoui, H. and Belghit, R. 2016. Energy efficiency of a photovoltaic cell based thin films CZTS by SCAPS. Journal of Fundamental and Applied Sciences, 8(2): 363-371.

21. Omrani, M. K., Minbashi, M., Memarian, N. and Kim, D. H. 2018. Improve the performance of CZTSSe solar cells by applying a SnS BSF layer. Solid-State Electronics, 141: 50-57.

22. Boumaour, M., Sali, S., Kermadi, S., Zougar, L., Bahfir, A., \& Chaieb, Z. 2019. High efficiency silicon solar cells with back ZnTe layer hosting IPV effect: a numerical case study. Journal of Taibah University for Science, 13(1): 696-703.

23. Khattak, Y. H., Baig, F., Toura, H., Beg, S. and Soucase, B. M. 2019. CZTSe Kesterite as an Alternative Hole Transport Layer for MASnI 3 Perovskite Solar Cells. Journal of Electronic Materials, 48(9): 5723-5733.

24. Khattak, Y. H., Baig, F., Ullah, S., Marí, B., Beg, S. and Ullah, H. 2018. Enhancement of the conversion efficiency of thin film kesterite solar cell. Journal of Renewable and Sustainable Energy, 10(3): 033501.

25. Simya, O. K., Mahaboobbatcha, A., \& Balachander, K., 2016. Compositional grading of CZTSSe alloy using exponential and uniform grading laws in SCAPS-ID simulation. Superlattices and Microstructures, 92: 285-293.

26. Olopade, M., Adewoyin, A., Chendo, M. and Bolaji, A. 2017. The Study of Some Materials as Buffer Layer in Copper Antimony Sulphide (CUSbS ${ }_{2}$ ) Solar Cell Using SCAPS 1-D. In 2017 IEEE 44th Photovoltaic Specialist Conference (PVSC) (pp. 2381-2384). IEEE.

27. Löckinger, J., Nishiwaki, S., Weiss, T. P., Bissig, B., Romanyuk, Y. E., Buecheler, S. and Tiwari, A. N., 2018. $\mathrm{TiO}_{2}$ as intermediate buffer layer in $\mathrm{Cu}$ (In, Ga) Se2 solar cells. Solar Energy Materials and Solar Cells, 174: 397-404.

28. Eisele, W., Ennaoui, A., Schubert-Bischoff, P., Giersig, M., Pettenkofer, C., Krauser, J. and Karg, F., 2003. XPS, TEM and NRA investigations of $\mathrm{Zn}(\mathrm{Se}, \mathrm{OH}) / \mathrm{Zn}(\mathrm{OH}) 2$ films on $\mathrm{Cu}(\mathrm{In}, \mathrm{Ga})(\mathrm{S}$, Se) 2 substrates for highly efficient solar cells. Solar energy materials and solar cells, 75(1-2): $17-26$.

29. Sawicka-Chudy, P., Sibiński, M., Wisz, G., Rybak-Wilusz, E., \& Cholewa, M., 2018. Numerical analysis and optimization of $\mathrm{Cu} 2 \mathrm{O} / \mathrm{TiO} 2, \mathrm{CuO} / \mathrm{TiO} 2$, heterojunction solar cells using SCAPS. In Journal of Physics: Conference Series (Vol. 1033, No. 1, p. 012002). IOP Publishing.

30. Najim, A. H., \& Saleh, A. N., 2019. Study effect of window and BSF layers on the properties of the CZTS/CZTSe solar cell by SCAPS-1D. Tikrit Journal of Pure Science, 24(3): 77-83.

31. Rosly, H. N., Rahman, K. S., Harif, M. N., Yusoff, Y., Wafi, A., Matin, M. A., ... \& Amin, N., 2019. High Efficiency CdTe Thin Film Solar Cells with CdSe as a Prospective Window Layer from Numerical Optimization. The Mattingley Publishing Co., Inc. ISSN: 0193-4120, 81: 5647 5653.

32. Jariwala, A., Chaudhuri, T. K., Toshniwal, A., Patel, S., Kheraj, V. and Ray, A. 2018. $\mathrm{SnS}_{2}$ films deposited from molecular ink as Cd-free alternative buffer layer for solar cells. In AIP Conference Proceedings, (Vol. 1961, No. 1, p. 030026). AIP Publishing LLC.

33. Mandadapu, U., Vedanayakam, S. V. and Thyagarajan, K. 2017. Simulation and analysis of lead based perovskite solar cell using SCAPS-1D. Indian Journal of Science and Technology, 10(11): 65-72.

34. Juha, K. and Sergey, V. 2005. Breakdown phenomena in semiconductors and semiconductor devices, (Vol. 36). World Scientific.

35. Zohra, C. F. 2012. Study of Silicon Solar Cells Performances Using The Impurity Photovoltaic Effect. (Doctoral dissertation). Department of Physics، College of Science، Université Ferhat Abbas-Setif، Algeria. 